\title{
Checking the United Nations: A Checklist Evaluation of United Nations Specialized Agencies Serial Publications
}

\author{
AMALIA MONROE \\ University of Kansas, Lawrence, KS
}

During the spring and summer of 2008 the University of Kansas (KU) Libraries conducted a collection evaluation study on the serial sales publications issued by United Nations (UN) specialized agencies. After a checklist was compiled, KU holdings were compared to the list to develop a record of $\mathrm{UN}$ specialized agency serial publication holdings at KU. The goal was to identify both electronic and print holdings within this specific collection. The project also sought publications that were freely available electronically for the purpose of expanding the KU international government information collection while neither increasing the serials budget nor the physical size of the collection.

KEYWORDS: United Nations, collection evaluation, government documents, University of Kansas, serials

Address correspondence to Amalia Monroe, Social Sciences Librarian, Collection Development, Anschutz Library, University of Kansas, 1301 Hoch Auditoria Drive, Lawrence, KS 66045. Email: almonroe @ ku.edu.

\section{Introduction}

Collecting, retaining, and making government information available to the public is an essential function of some libraries. Governments at all levels produce vital documents and publications that not only inform the citizenry, but are also an integral part of scholarly research. Managing 
these collections, however, is a challenging task because of the unique characteristics of these materials. Acquiring, cataloging, and providing access to information is time consuming and requires a certain level of expertise on the behalf of collection managers.

In today's academic environment, with an increased focus on accountability because of the current economic climate, libraries are being asked to justify budget expenditures with evidence-based reasoning. Collection assessments and evaluations applied to general monographic and serial collections are effective tools for developing rational collection decisions by libraries. In contrast, government information collections, especially international government collections, are rarely evaluated because many items are acquired through depository programs. It is inaccurate, however, to characterize such collections as "cost free" because of overhead costs, such as processing time, shelving costs, and preservation of resources (Skaggs 2006). In addition, many items that are vital components of these collections must be purchased because they do not come on deposit. Assumptions that such collections are necessary regardless of demonstrated use or demand are common, especially in large research libraries.

Government information collections may not be fully utilized because of the lack of training among librarians and library patrons. Furthermore, there are challenges in accessing these resources that is also a factor in their low usage. The following description of a collection evaluation study of the international government information collection at $\mathrm{KU}$ does not dispute the vitality of these collections. Rather the project allowed for identification of holdings of a specific portion of the international government information collection, furthered understanding of this portion, and simultaneously increased access and use of these important but underutilized resources. 


\section{Literature Review}

Few articles have been written specifically addressing evaluation and assessment of government information collections, and specifically checklist projects. Lack of research in this area may be due to several factors: inherent difficulties with managing government information collections, time constraints of librarians responsible for managing such collections, and challenges associated with developing an assessment tool. It may also be due, in part, to assumptions that government information collections should ideally be comprehensive. Furthermore, international government information collections are not as common as federal government information collections; therefore, authoritative checklists are even less likely to be compiled.

Beyond the difficulties associated with finding authoritative lists, there is little information that addresses freely available international government information on the web. Articles discussing electronic government information almost solely address United States government information, and this information is difficult to apply to the needs of international collections. While the similar concepts of harvesting publications on the web apply, different tools and methods are needed for these different types of government information collections.

In the case of this study, the process of compiling a suitable publications checklist for $\mathrm{KU}$ was informed by several sources, most of which discuss the advantages and limitations of utilizing the checklist method for collection evaluation. Johnson, in the widely used text Fundamentals of Collection Development and Management, explains that the checklist approach is an easy method to use, in part, because of the wide availability of authoritative lists for general collections (2004). Authoritative lists serve as the foundation for any checklist project. Authors cite such resources as Books for College Libraries as starting points (Lundin 1989). However, as 
was evident from the literature, there was no such list available for UN specialized agency serial publications, nor were any lists found for the select UN agencies' serial publications included in the study.

While advantages exist in using the checklist method, disadvantages of this method were considered during the process, including the subjective nature of checklists, lack of inclusion of a library's entire collection, and judgments made from assumptions of quality (Johnson 2004). Still, other problems exist with the checklist method beyond the subjectivity and quality of lists. Determining what percentage of books a library owns to define a superior, adequate, or insufficient collection creates another obstacle. Dennison stated "the acceptability or not of that percentage is usually not addressed by the study but is left to a subjective interpretation" (2000, 24-25). Dennison found that even when applying different methodological tools aimed at eliminating the obstacle, such as a tiered-list approach, the problem of defining adequacy still exists (2000). Another possible avenue to overcoming this problem is to assess results from a checklist project based upon a specific collection's goals and/or policy. However, this method of analysis was not applied to the KU project because of the lack of such documentation.

Robinson's articles, "Evaluation of the Government Documents Collection: A Step by Step Process" and "Evaluation of the Government Documents Collection: An Introduction and Overview," are essential for planning evaluations of government information collections because of the thorough discussions of not only potential methods, but also the focus on the continual goal of meeting the user's needs $(1981,1982)$. Both "user-centered" and "collection-centered" approaches are considered; however, the "user-centered" approach is the focus of these articles. While Robinson does not detail how to conduct a checklist evaluation for government collections, these articles together provide a foundation for evaluating government information 
collections by focusing on the user. While checklist evaluations may be considered more "collection-centered," the results of such projects can lead to actions that are "user-centered." The KU project incorporated a "user-centered" component to the basic checklist project by including the electronic availability of publications in the quality measure in the checklist.

A project at Jacksonville State University's Houston Cole Library provides insight into another approach to collection assessment (Skaggs 2006). The project at Jacksonville State adapted the OCLC/WLN conspectus method to assess an integrated government information collection; one component of the project was utilizing the checklist method. Core publication lists were identified for United States government information, easing the overall evaluation process when compared with evaluating international collections. The article demonstrates that the checklist method can be successfully applied to United States government information collections, but also highlights the difficulties faced when attempting a similar project with international government information collections.

One of the major obstacles with the literature is lack of currency; the majority of articles were published at least six years ago, with most published fifteen or more years ago. The lack of currency limits the information available on electronic government information. However, a recent book published by ALA, Managing Electronic Information: Issues and Practices, addresses current issues related to electronic government information (2008). In the chapter, "Managing Electronic International Government Information: Issues and Practices" by Morse, similar issues to those of the KU study are discussed, including sustained access to freely available materials and the maintenance of these in library catalogs (2008). Another issue highlighted is the major library-related concern about the lack of archival policies that intergovernmental organizations (IGOs) have in place, specifically for born-digital documents 
(2008). The chapter is also useful for new collection managers interested in an introduction to electronic international government information in a concise manner but there is a lack of introductory sources specifically addressing international government information.

In summary, the literature specifically addressing evaluations of government information collections is sparse, dated, and practically nonexistent in the international area. However, the preceding articles and chapters are important for understanding the process and issues with checklist evaluations of library collections and the complexities of managing government information.

\section{Collection Description}

The international government information collection at KU plays a role in the Libraries' mission of supporting teaching and research at the university. An UN and European Union (EU) depository, KU Libraries also provides an important public service by making such materials freely available to the public. IGOs and non-governmental organizations (NGOs), which make up the largest part of the international government information collection, provide a wealth of information, including statistics and research reports that support all disciplines.

As a United Nations depository, KU Libraries receives

Official Records of main organs of the United Nations, most sales publications regardless of place of issuance, the United Nations Treaty Series, all periodicals normally available by subscription and masthead documents (i.e., working documents) of the regional commission located in the area of the library " (United Nations 2007).

The terms "international documents" and "international government information" (used interchangeably) do not adequately describe the complex nature of the collection, nor does depository status demonstrate how budgetary constraints necessitate a collection review. The 
UN, for example, distributes "documents" on deposit, such as official documents released by the Security Council. Libraries in developed countries pay a fee of $\$ 1000$ for "regular deposit" and \$1750 for "print plus deposit" annually to be a UN depository (United Nations Department of Public Information 2007).

Further, a large portion of the information most frequently used is not received on the depository program and must be purchased separately, including documents and publications of UN specialized agencies and related agencies (i.e. United Nations Development Fund for Women, International Court of Justice, and others). These purchased materials include many of the essential statistical yearbooks and working papers published by UN agencies. Currently, KU Libraries has standing orders with several distributors and agencies, including Bernan Associates, the International Monetary Fund (IMF), and the United Nations Educational, Scientific, and Cultural Organization (UNESCO) to fill in gaps left by the depository program.

\section{Reasons for Conducting the Evaluation Project}

Managing these collections is challenging because of the nature of the materials. Decisions must be made not only on acquisition of specific publications, but also format (chiefly electronic or print), and from several sources, including depository plans, vendors, and direct sales (Eckman 2001). The international government information collection at KU has been somewhat neglected for a number of years, especially because of lack of time by collection managers to evaluate acquisitions from these multiple sources. With the assignment of a new collection manager, the opportunity arose for a collection evaluation that would subsequently lead to more informed collection management. 
As an initial action, a small-scale collection evaluation project was conducted as a step toward a larger-scale and continuing program of collection assessment. From the beginning, the overall goal of the project was to increase access and visibility, streamline collection development, assist with outreach and instruction efforts, and increase overall service quality for library patrons. Many possible benefits and outcomes were identified during the inception of the project, and, as was previously noted, assessing quality, breadth, or usefulness of these collections differs from similar activities with other library collections because of the uniqueness of these materials.

During the early phases of the project, a central reason identified for conducting the study was to develop a basic understanding of the quality of one portion of the international government information collection at KU and answer the question: does KU Libraries hold the core UN specialized agencies publications? The term "quality" when applied to collections is controversial because of the inherent subjectivity of defining what quality means for individual collections (Johnson 2004). Quality, for the purpose of this project, was defined as the measure of the comprehensiveness of the identified components of the international government information collections in relation to the needs of KU Libraries. However, comprehensiveness was only the first part of the quality measure included the in KU study. Accessibility was the second component to the quality measure because the ability to retrieve materials equates to quality library service, and affects perceived collection quality.

Electronic and print formats were distinguished during the data collection process. The electronic access to publications increases access and visibility, which can lead to an increase of use and patron satisfaction, an important goal for KU Libraries. Increasingly, international organizations, such as the UN, are making publications freely available on the web. Such 
developments allow libraries to expand collections without increasing serials budgets beyond initial cataloging and maintenance costs (West 2008). A library can hold all of the materials, but if inaccessible, than they are of much less use. William C. Robinson suggests, "the purpose of a documents collection is to maximize user satisfaction by providing needed information and at a reasonable cost" $(1981,111)$. The literature also suggests that government information is not heavily used for research and it is possible to see even less use with international collections (Reeling 1991). Access in less-preferred formats, such as print, may now be a contributing factor to low usage of these collections.

A secondary benefit of the project was starting documentation of the international government information collection that will provide a foundation for continued assessment by current and future collection managers. As the incoming collection manager, the author was unable to develop a comprehensive understanding of how the collection evolved, or why previous collection-related decisions were made. Improved documentation will assist in the development of a collection that will support current and future development and weeding decisions. The creation of this kind of documentation will also aid in the formation of an international government information collection development policy, something currently lacking within KU Libraries. Such collection-specific policies are important because they assist with selection/de-selection decisions, evaluating approval plans, and helping patrons understand the scope and goals of the collection (Olaojo 2006).

Budgetary considerations were another major motivation for this study. As with many academic libraries, KU Libraries faces decreased collection funds, and the international government information collection is no exception. This project not only allowed for identifying gaps in the collection, but also allowed for identifying freely accessible alternatives for collection 
enhancement without the added expense of additional subscription costs. Cost-saving measures, such as identifying publications for print cancellation or for reducing on-site storage, were other possible advantages of the project.

Increasing the collection manager's knowledge of KU's holdings was another motivation for undertaking the project. Learning about international government information is a challenging task. Completing a checklist evaluation can greatly enhance knowledge of the collection and these types of publications as a whole. Managing this type of collection often requires "on the job" training over an extended period in order to develop expertise with the material.

Finally, the project can assist with the design and implementation of regular, more usercentered collection evaluations (Johnson 2004). Establishing a better understanding of the collection will inform future projects; it is better to be knowledgeable about current holdings before asking patrons what they need. Subsequent assessment and understanding of user's needs provides a strong foundation for implementing effective instruction efforts, collection development decisions, and reference services that can increase the visibility and use of the collection for researching and teaching purposes. These results could also assist with justifying the collection in response to calls for accountability. Utilizing and combining all evaluation methods is helpful to accomplishing the goals associated with user-centered collection management.

\section{Evaluating the Collection}




\section{Scope}

United Nations specialized agencies serial publications and ten other UN agencies with key publications were the focus of this assessment because of their non-depository status. Ideally, checking depository items from the United Nations would be included; however, a smaller portion of the collection was selected for efficiency and effectiveness of the study. These documents also represent important publications that should be included in a large research library's collection.

The official organizational chart of the United Nations was used to initially identify what are referred to as the "United Nations Specialized Agencies" (United Nations Department of Public Information 2007). There are discrepancies as to how different agencies and commissions are categorized, further demonstrating the complexities with international government information. Therefore, the author as an additional source for understanding the UN organizational structure, consulted The Directory of United Nations Documentary and Archival Sources (Hajnal 1991). Select UN Regional Commissions were likewise included in the study because of the importance of their publications (Church 2004). The publications produced by these additional commissions disseminate information to external audiences, including scholars, served by academic research libraries.

Serial publications were selected because the ultimate benefits of measuring this part of the collection currently outweigh analyzing only depository documents. They are one of the largest components of the collection, whose size and cost provide the opportunity for the greatest space and monetary savings. Yearbooks and annual statistical sources were included as serials. Even though these publications are often excluded from the traditional definition of serials, they 
are nonetheless important information sources often considered core publications of these agencies.

\section{Methodology}

The checklist method was selected over other methods because of the unique nature of government information. For example, circulation statistics, a standard measure of usage for monograph collection, do not accurately reflect how often government collections are used since many of these items are used in-house, and such statistics are not collected for this collection by KU Libraries.

The project was comprised of three elements after establishing the scope:

1. Creating a checklist of select publications

2. Checking the list against KU Libraries holdings

3. Adding new electronic publications to KU Libraries holdings

\section{Creating a Checklist}

Compilation of the list began with identifying serial indexing of UN specialized agency publications and other select UN agencies using Ulrich's online database. From this list, multiple sources were used to find missing titles and to narrow the list to "core publications."

Each publication included in the selected sources consulted was recorded, and those publications that appeared in the most guides were added to the final checklist. The final list of publications included 158 titles from 31 agencies (see Appendix A).

Ideally, the final list is a comprehensive list of core UN specialized agencies serial publications. The list was compiled independently of KU holdings in order to create a non- 
biased picture of the collection. However, the goal of a non-biased list may not have been fully realized because of the possible presence of author bias, and existing bias in the previously published lists used, during the compilation process.

One major challenge during the compilation process was finding current sources. The existing lists are either comprehensive, which do not identify "core" publications, or they are selective lists from individual years that only include specific documents within publications or monographs. All published comprehensive bibliographies were at least ten years old. The annual compilations of suggested international government documents compiled by Van Fossen and Hinton were utilized during the compilation process to increase currency of the KU checklist (1999, 2000, 2002, 2004). However, these compilations only include monographs and specific documents within serials, such as reports; therefore, the publications in which individual documents appeared were added to the KU list for consideration. For example, Van Fossen and Hinton selected "Wholesale Market Management: A Manual" which is a document within the publication FAO Agricultural Services Bulletin No. 1 (2000). This serial publication, FAO Agricultural Services Bulletin, was marked for possible inclusion in the KU checklist. Academic library guides to international documents were also used to increase the timeliness of the checklist. Finally, the lack of published sources necessitated the inclusion of, when possible, best selling or featured items on agency websites.

Additional obstacles arose in the selecting of agency publications for inclusion in the checklist as core publications. The lack of consistency of agency coverage was a major challenge during the compilation process because not all agencies were covered by every source. It necessitated the need to have some flexibility in the criteria about whether to include a publication or not on the list. With the agencies that publish few serials, publications were 
included as core titles if they were considered important by two or more sources. Publications from agencies that publish a greater numbers of serials were included if they were considered important by four or more sources. Using the same criteria for all agencies would have eliminated several agencies that are integral for a quality international government information collection.

\section{Checking the List}

After finalizing the list, student assistants checked all publications against KU holdings, which were checked again by the author. The number of titles per agency varied greatly from one to 11 . The student assistant checked each title under seven categories:

1. KU print holdings $(\mathrm{y} / \mathrm{n})$

2. KU print holdings (years)

3. KU catalog electronic access $(\mathrm{y} / \mathrm{n})$

4. KU e-journal search access $(y / n)$

5. Publishing agency publication electronic access $(\mathrm{y} / \mathrm{n})$

6. Publishing agency publications electronic access holdings (years)

7. Publishing agency web archival policies $(\mathrm{y} / \mathrm{n})$

After the author checked the titles again to ensure the greatest possible accuracy of the results, three lists were sent to the Acquisitions/Serials and Cataloging Departments:

1. New electronic access for titles that $\mathrm{KU}$ has in print

2. New electronic access for titles that $\mathrm{KU}$ does not have in print

3. Inaccurate records. 


\section{Adding Records}

The Acquisitions/Serials and Cataloging Departments investigated the viability of adding any titles from the three lists submitted. The submitted lists included 31 titles identified as only currently available in print, 16 titles not currently available electronically with no print holdings, and two inaccurate records. The three lists were checked for current access, the possibility of tracking through Serial Solutions (E-Resource Access and Management (ERAMS) service), and the possibility of adding electronic access in the KU catalog without Serial Solutions tracking. The Acquisitions/Serials and Cataloging departments found that 11 titles initially identified as not being currently accessible electronically through KU were already tracked through Serial Solutions, reducing the number of possible new titles to 36 . This finding demonstrates the importance of multiple checks during this type of project.

The titles provided were initially searched in KU's e-journal search and catalog. If the title was not found, it was then searched in Serial Solutions. There were four possible results after the Serial Solutions search:

1. Title listed in Serial Solutions, treated as a journal, and tracked by KU

2. Title listed in Serial Solutions; treated as a journal, and not tracked by KU

3. Title listed in Serial Solutions, treated as book, and not tracked by KU

4. Title not listed in Serial Solutions

After these searches were conducted, eligible titles were added to the catalog and/or e-journal search through the KU Libraries' web site. 


\section{Results}

Table 1: Results of Checklist (Print and Electronic Access)

\begin{tabular}{|c|c|}
\hline Titles on checklist & 158 \\
\hline $\begin{array}{l}\text { Titles with current print OR electronic } \\
\text { access }\end{array}$ & $100(63 \%)$ \\
\hline Titles with NO access & $58(37 \%)$ \\
\hline Titles with only print access & $\begin{array}{l}69 \text { ( } 44 \% \text { of list holdings) ( } 69 \% \text { of } \mathrm{KU} \\
\text { holdings) }\end{array}$ \\
\hline Titles with only electronic access & $4(.03 \%)$ \\
\hline Titles with both print and electronic access & $\begin{array}{l}27(17 \% \text { of list holdings) ( } 27 \% \text { of } \mathrm{KU} \\
\text { holdings) }\end{array}$ \\
\hline
\end{tabular}

uded on the final checklist of core UN specialized serial publications, KU holds $100(63 \%)$ in at least one format (print or electronic). Sixty-nine of these titles are in print only, four electronic only, and 27 are available in both print and electronic.

Table 2: Electronic Records Added to KU Holdings

\begin{tabular}{|l|l|}
\hline Total titles added & 24 \\
\hline Titles added with current print access & 22 \\
\hline Titles added with no current access & 2 \\
\hline
\end{tabular}

Thirty-six titles were identified as possible additions to the KU collection through freely available electronic sources. Out of these, 24 titles were added to KU holdings. The number of print only titles decreased from 69 to 45 , for a resulting $16 \%$ increase of titles with both print and 
electronic access. Only two entirely new titles were added to KU holdings; however, holdings were ultimately expanded. Some titles already available in print were not complete collections. For example, KU only held three years of the State of the World Population (UNFPA) in print, even though publication began in 1996. The KU catalog and e-journal search now link to all years, which are freely available through the agency's web site.

Since there are no other studies on which to base any comparison, it is difficult to make complete conclusions about the quality of the KU collection using the criteria "percent of holdings." Ideally, as a research library, KU would hold $100 \%$ of the titles; however, total coverage is not currently possible. It is promising to find that KU holds $63 \%$ of the identified titles in some format; however, out of total titles held only $37 \%$ are available in electronic format. Since 24 titles with electronic access were added to the collection because of the project, the results suggest that electronic availability represents one aspect of the collection that should and can be improved with little cost. Before this study, less than half of KU Libraries holdings were available electronically.

One step toward making the international government information more readily accessible was achieved. However, additional collection improvements may not be possible at this time because no electronic access is currently available or there is no freely available access for the remaining publications. Further comparison with peer libraries would help establish a context of the results of the KU project. Such comparisons would present additional challenges because of the difficulties in accurately identifying international government holdings in these peer institutions, as was the case with KU. 
A disappointing but not surprising result was that no print publications were identified for cancellation because the cost savings would be minimal and would have necessitated a review of the bundled packages with publishers. As more titles become available freely on the web, print subscriptions may be reduced if these free electronic titles include substantial print titles currently received in bundled packages. A concerted effort will be made to periodically check the newly developed core list for increased access to more titles. The possibility of increasing titles and electronic access reinforces the benefit of continual evaluation of collections.

The web archival policies category did not produce significant information. This result is indicative of the overall problem with the lack of web archival policies from IGOs (West 2008). The lack of archival policies presented challenges about deciding what records should be added because the publications may not be permanently available. In most cases, the author and Acquisitions/Serials and Cataloging Departments chose to include titles unless it was entirely clear that access would be inconsistent.

A significant result of the project was the increased knowledge of UN publications gained by the collection manager and members of the Acquisitions/Serials and Cataloging Departments. The UN and related agencies' publication system is vast and confusing. The KU study allowed the collection manager to more closely examine the structure and develop a greater understanding of the relationships among organizations, which evolves into more accurate and efficient service to researchers. Members of other library departments also learned more about what publications KU currently has access to and what and how other UN titles can be added through Serial Solutions, and gained a better understanding of what titles are considered desirable. Library staff also learned more about the inconsistency of URLs and the best URL to use to ensure permanent access to publications. 
Since the completion of the project, the results generated proved beneficial during a reference collection review and assisted with decisions regarding collection moves to off-site storage. Effective decision-making was possible because not only did the project increase the author's knowledge of what is currently available electronically, but it also enhanced the understanding of the quality and durability of the electronic access of certain publications/agencies. The latter is an essential consideration when switching to reliance upon freely available electronic publications.

\section{Limitations}

The KU study presented many challenges and has inherent limitations. Two of the major and interrelated limitations of the study were lack of selective bibliographies and currency of resources covering UN specialized agencies. For example, the absence of selective bibliographies required piecing together different resources to compile the final list. Nontraditional sources, such as web guides and agency web sites, were utilized because of their currency and their ability to fill in the gaps for lesser-covered agencies. These guides are limited because they lack the "authority" of published lists and the possible presence of publisher/author bias. These limitations could have negatively affected the quality of the KU project final list. However, these lists were chosen by author reputation and institutional affiliation to avoid such problems.

Another limitation was the fact that publications cease and then continue under different titles. A great effort was made to identify all such cases, but some may have been overlooked. Ulrich's, WorldCat, and published guides were used to identify these types of publications. 
During the actual list checking, more ceased publications were identified and they were eliminated at this stage of the project.

The methodology was as accurate as the available resources allowed for the KU project. The completed list provided a basis for KU Libraries to begin an evaluation of the international government information collection. The list may also serve as starting point for other collection evaluators to adapt for their institutions.

\section{Conclusion}

A literature search revealed that librarians have conducted relatively few studies aimed toward analyzing both international government information collections and U.S. government information collections. The lack of available literature demonstrates the problems associated with collection evaluation of government information. While small in scope, the overall process utilized at KU may be useful for other libraries considering assessing their government information collections. The KU study may also be useful for libraries that are considering starting or expanding an international government information collection that would not require additional subscription costs.

All library staff involved in the project learned more about the collection and about the process of adding freely available electronic serial records. KU added 24 titles (16\% of total titles on the list) to the collection without additional subscription costs. In addition, the project was one step toward increasing access to an under-utilized collection, and toward creating a documented process for such endeavors. The project also demonstrated that while the potential 
for increasing international government information holdings is great, regular evaluation is necessary to ensure that they remain available.

After the initial evaluation, a second user-centered study could be implemented to increase visibility of the collection as well as use among researchers. This second step would increase the quantity and effectiveness of outreach efforts, including training sessions, web presence, and other guides. Some of the possibilities include a user survey of faculty, students and other researchers and analyzing circulation statistics and/or electronic publication usage statistics. Outcomes from these activities could include understanding how researchers use or do not use the collection and identification of collection ineffectiveness (i.e., are we missing important publications or agencies).

The KU project is an example of the changing face of collection management in academic libraries today. Libraries no longer have the ability to continue expanding both print and electronic collections because of lack of physical space, inadequate budgets, and increasing serial costs. Seeking alternatives in order to provide quality resources and services to our researchers is therefore more necessary than ever. The Internet now provides significantly greater opportunities to improve and expand library services at little or no cost and government information has become much more accessible. This growth will continue because of the increase of "born-digital" publications and digitization projects. Hopefully, the use of these resources will increase, and both library researchers and librarians will fully realize the potential of such collections. 


\section{REFERENCES}

Church, James A. 2004. Filling in the Gaps: Issues and Strategies for Collection Development in the United Nations Depository Libraries. Journal of Government Information 30, no.1: 819.

Dennison, Russell F. 2000. Quality Assessment of Collection Development through Tiered Checklists: Can You Prove that You are a Good Collection Developer? Collection Building 19, no. 1: 24-26.

Eckman, Chuck. 2001. Acquiring International Documents: Challenges, Strategies, and Sources. Journal of Government Information 28, no. 2: 179-183.

Hajnal, Peter I. 1991. Directory of United Nations Documentary and Archival Sources. New York: United Nations and Kraus International Publications.

Johnson, Peggy. 2004. Fundamentals of Collection Development and Management. Chicago: American Library Association.

Lundin, Anne H. 1989. List-Checking in Collection Development: An Imprecise Art. Collection Management 11, no. 3/4: 103-112.

Morse, Catherine. 2008. Managing Electronic International Government Information. In Managing Electronic Government Information in Libraries: Issues and Practices, edited by Andrea Morrison, 195-208. Chicago: American Library Association.

Olaojo, P. Olatunji and M.A. Akewukereke. 2006. Collection Development Policies: Grounds Rules for Planning University Libraries. Library Philosophy and Practice 9, no. 1: 1-5..

Reeling, Patricia, Mary Fetzer, Daniel O'Connor. 1991. Use of Government Publications in an Academic Setting. Government Publications Review 18: 489-515.

Robinson, William C. 1981. Evaluation of the Government Documents Collection: An Introduction and Overview. Government Publications Review 8a: 111-125.

Robinson, William C. 1982. Evaluation of the Government Documents Collection: A Step-byStep Process. Government Publications Review 9: 131-141.

Skaggs, Bethany Latham. 2006. Assessing an Integrated Government Documents Collection. Collection Building 25, no. 1: 14-18.

United Nations. 2007. United Nations Depository Library System. December 7, 2007. http://www.un.org/Depts/dhl/deplib/deplibsystem.htm (accessed April 28, 2009). 
United Nations Department of Public Information. 2007. The United Nations System: Principal Organs. The United Nations. December 122007. http://www.un.org/aboutun/chart_en.pdf (accessed June 6, 2009).

Van Fossen, Michael, and Paula P. Hinton. 1999. United Nations and Other International Organizations. Journal of Government Information 26, no. 6: 727-745.

Van Fossen, Michael, and Paula P. Hinton. 2000. United Nations and Other International Organizations. Journal of Government Information 27, no. 6: 857-882.

Van Fossen, Michael, and Paula P. Hinton. 2002. United Nations and Other International Organizations. Journal of Government Information 29, no. 2-4: 249-278.

Van Fossen, Michael, Paula P. Hinton, and Beth L. Rowe. 2004. United Nations and Other International Organizations. Journal of Government Information 30, no. 2/3: 280-311.

West, Amy. 2008. The Impact of Technology on Managing Access to Electronic Government Information in Libraries. In Managing Electronic Government Information in Libraries: Issues and Practices, by ed. Andrea M. Morrison, 14-20. Chicago: American Library Association.

\title{
APPENDIX A: CORE SERIAL PUBLICATIONS OF UNITED NATIONS SPECIALIZED AGENCIES
}

\author{
Agency Publication \\ ECA Africa Statistical Yearbook \\ ECA Economic Report on Africa \\ ECA Foreign Trade Statistics for Africa \\ ECA Population Newsletter \\ ECA Statistical Information Bulletin for Africa \\ ECA Survey of Economic Conditions \\ ECE Annual Bulletin of Transport Statistics for Europe \\ ECE East-West Investment News \\ ECE Economic Bulletin for Europe \\ ECE Economic Survey of Europe \\ ECE Statistical Journal of the United Nations Economic Commission for Europe \\ ECE Trends in Europe and North America ECE Yearbook \\ ECLAC C E P A L Review \\ ECLAC Economic Survey of Latin America and the Caribbean \\ ECLAC Preliminary Overview of the Economies of Latin America and the Caribbean \\ ECLAC Statistical Yearbook for Latin America and the Caribbean \\ ESCAP Asia-Pacific Population Journal \\ ESCAP Economic and Social Survey of Asia and the Pacific \\ ESCAP Economic Bulletin for Asia and the Pacific \\ ESCAP Statistical Indicators for Asia and the Pacific
}




\begin{tabular}{|c|c|}
\hline ESCAP & Statistical Yearbook for Asia and the Pacific \\
\hline ESCWA & Agriculture and Development in Western Asia \\
\hline ESCWA & E S C W A Population Bulletin \\
\hline ESCWA & National Accounts Studies of ESCWA Region \\
\hline ESCWA & Prices and Financial Statistics in ESCWA Region \\
\hline ESCWA & Statistical Abstract of the Region of ESCWA \\
\hline ESCWA & Survey of Economic and Social Development in the ESCWA Region \\
\hline $\mathrm{FAO}$ & F A O Food and Nutrition Series \\
\hline FAO & F A O Yearbook, Trade \\
\hline FAO & F A O Yearbook, Fishery Statistics \\
\hline FAO & F A O Yearbook, Production \\
\hline FAO & State of the World's Forests \\
\hline FAO & The State of Food and Agriculture \\
\hline FAO & Yearbook of Forest Products \\
\hline IAEA & Annual Report \\
\hline IAEA & IAEA Bulletin \\
\hline IAEA & Resolutions and other decisions of the General Conference Statue \\
\hline ICAO & Civil Aviation Statistics of the World \\
\hline ICAO & I C A O Journal \\
\hline ICAO & ICAO Bulletin (preceded icao journal) \\
\hline ICAO & Council. Annual Report \\
\hline ICAO & Digests of Statistics. Series AT \\
\hline ICAO & Digests of Statistics. Series FP. \\
\hline ICAO & Digests of Statistics. Series TF. \\
\hline IFAD & Annual Report \\
\hline ILO & Bulletin of Labour Statistics \\
\hline ILO & International Labour Documentation \\
\hline ILO & International Labour Review \\
\hline ILO & Key Indicators of the Labour Market (KILM) \\
\hline ILO & Labour Education \\
\hline ILO & Labour Law Documents \\
\hline ILO & Official Bulletin \\
\hline ILO & World Employment Report \\
\hline ILO & World of Work, the magazine of the ILO \\
\hline ILO & Yearbook of Labour Statistics \\
\hline IMF & Finance and Development (Print Edition) \\
\hline IMF & International Financial Statistics \\
\hline IMF & Annual Report of the Executive Board \\
\hline IMF & Direction of Trade Statistics \\
\hline IMF & Government Finance Statistics Yearbook \\
\hline IMF & Staff Papers \\
\hline IMF & World Economic Outlook \\
\hline IMF & Summary Proceedings : Annual Meeting of the Board of Governors \\
\hline IMO & BC Code: Code of Safe Practice for Solid Bulk Cargoes \\
\hline IMO & I M O News \\
\hline IMO & International Maritime Dangerous Goods Code \\
\hline IMO & MARPOL 73 - 78 Amendments \\
\hline ITU & Report on the Activities \\
\hline ITU & ITU Newsletter \\
\hline ITU & Telecommunication Journal \\
\hline
\end{tabular}




\begin{tabular}{|c|c|}
\hline ITU & Yearbook of Public Telecommunications Statistics \\
\hline UNCTAD & Least Developed Countries Report \\
\hline UNCTAD & Review of Maritime Transport \\
\hline UNCTAD & Trade and Development Report \\
\hline UNCTAD & UNCTAD Bulletin \\
\hline UNCTAD & UNCTAD Commodity Yearbook \\
\hline UNCTAD & UNCTAD Review \\
\hline UNCTAD & World Investment Report \\
\hline UNDCP & Bulletin on Narcotics \\
\hline UNDP & Cooperation South \\
\hline UNDP & Human Development Report (Year) \\
\hline UNDP & National Human Development Reports (includes all individual country/regional reports) \\
\hline UNDP & UNDP Annual Report \\
\hline UNEP & EarthViews \\
\hline UNEP & Global Environment Outlook \\
\hline UNEP & Industry and Environment \\
\hline UNEP & Our Planet (Online Edition) \\
\hline UNEP & Our Planet (Print Edition) \\
\hline UNEP & Register of International Treaties and Other Agreements in the Field of the Environment \\
\hline UNEP & UNEP Annual Report \\
\hline UNEP & The State of the World Environment OR State of the Environment \\
\hline UNEP & World Resources \\
\hline UNESCO & Copyright Bulletin: Quarterly Review \\
\hline UNESCO & Educational Documentation and Information \\
\hline UNESCO & International Social Science Journal (co-published) \\
\hline UNESCO & Museum International \\
\hline UNESCO & UNESCO Courier ONLINE \\
\hline UNESCO & UNESCO Courier Print \\
\hline UNESCO & UNESCO Records of the General Conference. Proceedings \\
\hline UNESCO & UNESCO Report of the Director - General on the Activities of the Organization \\
\hline UNFPA & Annual Review of Population Law \\
\hline UNFPA & Inventory of Population Projects in Developing Countries Around the World \\
\hline UNFPA & State of World Population \\
\hline UNFPA & Annual Report \\
\hline UN-Habitat & Habitat Debate \\
\hline UN-Habitat & UN-Habitat Annual Report \\
\hline UNICEF & Progress for Children \\
\hline UNICEF & State of the World's Children \\
\hline UNICEF & Statistics on Children in UNICEF Assisted Countries \\
\hline UNICEF & The Progress of Nations \\
\hline UNICEF & Annual Report \\
\hline UNIDO & African Industry in Figures \\
\hline UNIDO & Handbook of Industrial Statistics \\
\hline UNIDO & Industrial Research and Development News \\
\hline UNIDO & Industry and Development: Global Report \\
\hline UNIDO & International Yearbook of Industrial Statistics \\
\hline UNIDO & UNIDO Newsletter \\
\hline UNRWA & Palestine Refugees Today \\
\hline UNWTO & Compendium of Tourism Statistics \\
\hline UNWTO & GATT W T O News \\
\hline
\end{tabular}




\begin{tabular}{|c|c|}
\hline UNWTO & Tourism Market Trends \\
\hline UNWTO & Yearbook of Tourism Statistics \\
\hline UPU & Biennial Report \\
\hline UPU & Postal Statistics \\
\hline UPU & Rapport Annuel/Annual Report \\
\hline UPU & Resolutions and Decisions of the Executive Council \\
\hline UPU & Union Postale \\
\hline WFP & World Food Programme Journal \\
\hline WFP & World Food Programme. Annual Report \\
\hline WHO & Bulletin of the World Health Organization (BLT) \\
\hline WHO & International Travel and Health: Vaccination Requirements and Health Advice \\
\hline WHO & The Work of WHO: Annual Report of the Director \\
\hline WHO & The World Health Report \\
\hline WHO & W H O Drug Information \\
\hline WHO & Weekly Epidemiological Record \\
\hline WHO & World Health Forum \\
\hline WHO & Handbook of Resolutions and Decisions of the World Health Assembly and the Executive Board. \\
\hline WIPO & Industrial Property, Statistics B. Part 1 - Patents \\
\hline WIPO & Industrial Property, Statistics B. Part 2 - Trademarks and Service Marks, \\
\hline WIPO & P C T Gazette \\
\hline WIPO & P C T Newsletter \\
\hline WMO & Annual Report WMO \\
\hline WMO & W M O Bulletin \\
\hline WMO & Special Environmental Reports \\
\hline World Bank & Environment Matters \\
\hline World Bank & Finance and Development \\
\hline World Bank & Global Development Finance \\
\hline World Bank & Global Economics Prospects \\
\hline World Bank & The World Bank Economic Review \\
\hline World Bank & World Bank Research Observer \\
\hline World Bank & World Bank. Annual Report \\
\hline World Bank & World Development Indicators \\
\hline World Bank & World Development Report \\
\hline WTO & International Trade Statistics \\
\hline WTO & Trade and Environment Bulletin (irregular) \\
\hline WTO & W T O Annual Report \\
\hline WTO & W T O Focus \\
\hline WTO & World Trade Report \\
\hline
\end{tabular}

